\title{
Surgical treatment of achilles tendon ruptures: the comparison of open and percutaneous methods in a rabbit model
}

\author{
Güney Yılmaz, M.D.,' ${ }^{1}$ Mahmut Nedim Doral, M.D., ${ }^{2}$ Egemen Turhan, M.D.,, \\ Gürhan Dönmez, M.D., ${ }^{2}$ Ahmet Özgür Atay, M.D., ${ }^{2}$ Defne Kaya, M.D. ${ }^{3}$
}

\begin{abstract}
'Department of Orthopaedics and Traumatology, Selcuk University Faculty of Medicine, Konya; 2Department of Orthopaedics and Traumatology, Hacettepe University Faculty of Medicine, Ankara; ${ }^{3}$ Department of Sports Medicine, Hacettepe University Faculty of Medicine, Ankara
\end{abstract}

\begin{abstract}
BACKGROUND: This study was intended to investigate the healing properties of open and percutaneous techniques in a rabbit model and compare histological, electron microscopical, and biomechanical findings of the healed tendon between the groups.

METHODS: Twenty-six rabbits were randomly assigned to two groups of thirteen rabbits each. Percutaneous tenotomy of the Achilles tendon (AT) was applied through a stab incision on the right side $1.5 \mathrm{~cm}$ above the calcaneal insertion in all animals. Using the same Bunnell suture, the first group was repaired with the open and the second group was repaired with the percutaneous method. ATs were harvested at the end of eight weeks for biomechanical and histological evaluation.

RESULTS: When the sections were evaluated for fibrillar density under electron microscopy, it was noted that fibrils were more abundant in the percutaneous repair group. The tendon scores in the percutaneous group were less than the open group indicating closer histological morphology to normal. The difference was not significant $(p=0.065)$. The mean force to rupture the tendon was 143.7 \pm 9.5 $\mathrm{N}$ in percutaneous group and 139.2 $\pm 8.2 \mathrm{~N}$ in the open group. The difference was not significant $(p=0.33)$.
\end{abstract}

CONCLUSION: Percutaneous techniques provide as good clinical results as the open techniques do. The healing tendon shows better findings in histological and electron microscopical level with percutaneous technique.

Key words: Achilles tendon; open repair; percutaneous repair.

\section{INTRODUCTION}

The incidence of Achilles tendon (AT) rupture is around eighteen per 100.000 people and it is more common in men aged 30 to 50 years. ${ }^{[1]}$ Although AT is the strongest tendon, it is most frequently ruptured. ${ }^{[2-4]}$ Autoimmune conditions, mechanical abnormalities of the foot, corticosteroid therapy, fluoroquinolone antibiotics, and exercise-induced hyperthermia are causative factors for AT ruptures. ${ }^{[5-9]}$ Ruptured ten-

Address for correspondence: Güney Yılmaz, M.D. Selçuk Üniversitesi Tıp Fakültesi Hastanesi, Ortopedi ve Travmatoloji Anabilim Dalı, Selçuklu, Konya, Turkey Tel: +90 332 - 24l 5000 E-mail: aflguney@hotmail.com

Qucik Response Code Ulus Travma Acil Cerrahi Derg 20|4;20(5):3।I-3। 8 doi: $10.5505 /$ tjtes.20I4.427I6

Copyright 2014 TJTES dons have more histological abnormalities than unruptured ones. $^{[10,11]}$

The treatment of AT ruptures includes conservative and surgical methods. ${ }^{[12]}$ Conservative treatments include fixed-angle casting or dynamic bracing; ${ }^{[13-16]}$ however, their complications including pressure sores, fungal skin infections, and blisters reduce patient compliance with the treatment. Moreover, conservative treatments are associated with high re-rupture rates and prolonged recovery time. ${ }^{[17]}$

Surgical treatments such as open and mini-open/percutaneous techniques enable early rehabilitation and faster return to pre-injury activity level. ${ }^{[18-2 \mid]}$ Open techniques ensure accurate appositioning of the tendon ends, and thus, more stable suture fixation. However, the paratenon supplying blood to the tendon is disturbed. ${ }^{[18]}$ The skin incision passes through poorly vascularized area on the posterior part of the distal calf causing morbidity such as dehiscence of the skin edges and delayed healing. ${ }^{[22,23]}$ 
Percutaneous repair of the AT preserves the tendon sheaths and the blood supply around the AT enabling early rehabilitation. ${ }^{[24-27]}$ However, percutaneous techniques have higher rerupture rates and sural nerve complications. In a meta-analysis; however, open and percutaneous repair have not differed significantly in terms of re-rupture and sural nerve injury. ${ }^{[28-30]}$

Studies of in vivo histological and biomechanical comparison of open and percutaneous techniques are limited. This study aimed to investigate the healing properties of open and percutaneous techniques in a rabbit model and compare histological, electron microscopic, and biomechanical findings of the healed tendon of both groups.

\section{MATERIALS AND METHODS}

\section{Animals}

Three-month-old skeletally mature New Zealand white rabbits ( $n=26,3.5 \pm 0.5 \mathrm{~kg}$, University of Ankara, Animal Laboratory, Ankara, Turkey) were housed in cages and exposed to a diurnal light cycle. Animals were fed regularly with commercially available rabbit food. The right hind legs were used for the study and the left legs were preserved as control group. The temperature was kept between $23^{\circ}$ and $25^{\circ} \mathrm{C}$. The Eth- ics Committee for Experiment on Animals of Hacettepe University in Ankara, Turkey approved all procedures done in this study.

\section{Experimental Design}

Twenty-six rabbits were randomly assigned to two groups of thirteen rabbits each. A percutaneous tenotomy of the AT was applied through a stab incision on the right side approximately $1.5 \mathrm{~cm}$ above the calcaneal insertion in all animals. Using the same suture technique, the first group was repaired with the open and the second group was repaired with the percutaneous technique. All animals participated in this study were followed by a veterinarian in the pre-operative period. The animals were sacrificed and the ATs were harvested at the end of eight weeks for biomechanical and histological evaluation.

\section{Surgical Procedure}

All surgical procedures were performed in a fully-equipped operation theatre inside the animal laboratory unit by the first and the senior authors (GY, MND). The animals were anesthetized after overnight fasting with a combination of Rompun ${ }^{\circledR}$ (Xylazine, $2 \mathrm{mg} / \mathrm{kg}$, Bayer, Germany) and $\operatorname{Ketalar}^{\circledR}$ (Ketamin HCL, 5
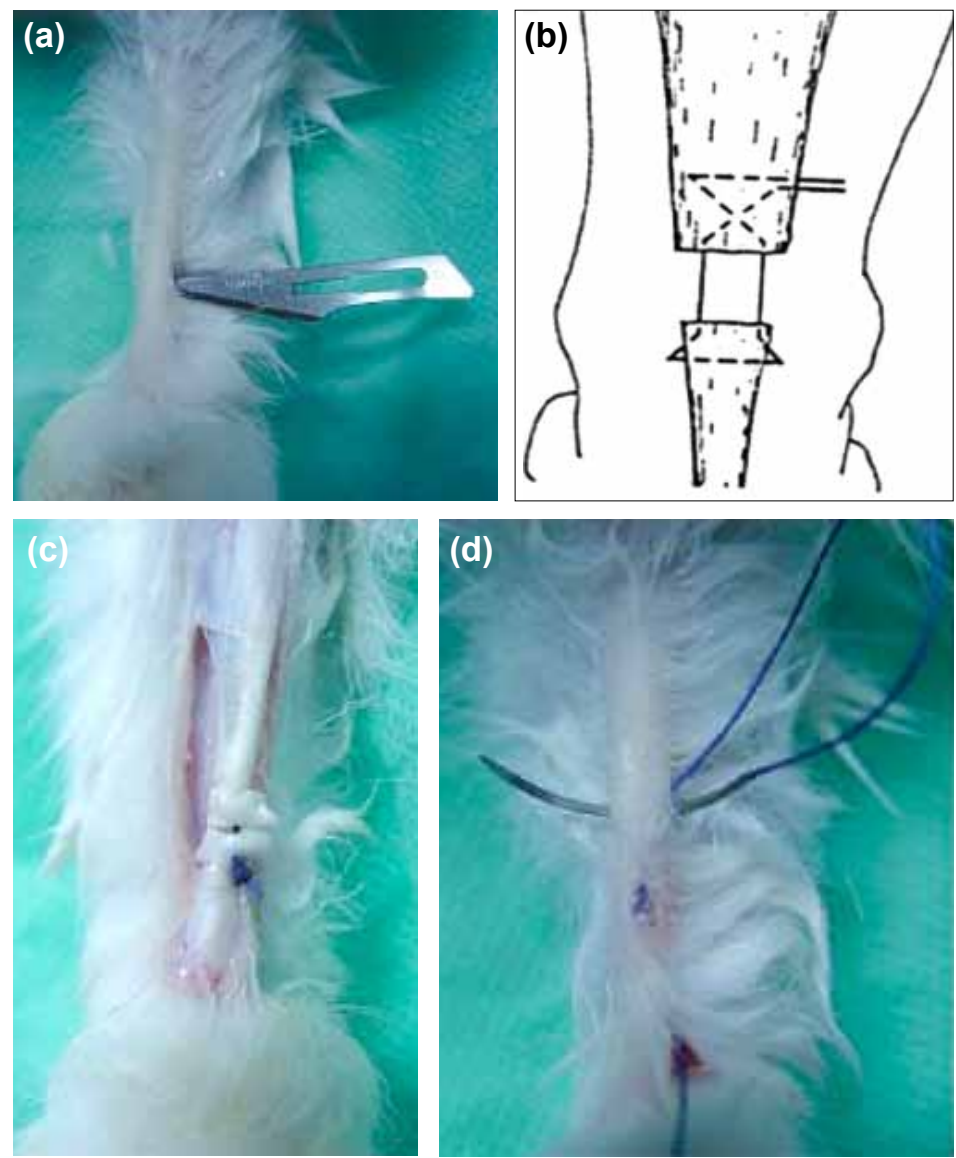

Figure 1. (a) Percutaneous Achilles tenotomy through a stab incision. (b) Suture technique used in both groups. (c) Open and (d) percutaneous repairs used in animals, respectively. 
$\mathrm{mg} / \mathrm{kg}$, Pfizer-USA) as a bolus injection. Pental Sodyum ${ }^{\circledR}$ (Penthotal sodium, $10-15 \mathrm{mg} / \mathrm{kg} / \mathrm{h}$. Ibrahim Ethem Ulugay, Istanbul, Turkey) was used for maintenance of the anaesthesia as a continuous intravenous infusion. A single dose of Lespor ${ }^{\circledR}$ (Cephazoline sodium, $20 \mathrm{mg} / \mathrm{kg}$, Ibrahim Ethem Ulugay, Istanbul, Turkey) was applied to all animals preoperatively. The animals were laid prone and the posterior parts of their legs were shaved. The surgical field was washed with povidone-iodine and subsequently covered with sterile drapes. A percutaneous tenotomy of the AT was applied through a stab incision on the right side approximately $1.5 \mathrm{~cm}$ above the calcaneal insertion in all animals (Fig. Ia). The stab incisions were kept as small as possible in order not to disturb the paratenon. Later, using the same suture technique (Fig. Ib) the first group was repaired with the open and the second group was repaired with the percutaneous technique. In the open group, the tendon ends were exposed after the stab incision was elongated proximally and distally. In the percutaneous group, the repair was achieved with the same suture technique through four (two proximal and two distal) stab incisions manually controlling the apposition of the tendon ends (Figs. Ic, d). The AT repair was carried out by Vicryl ${ }^{\circledR}$ (3.0, Polyglactin 910, Ethicon, USA) sutures. Left sided ATs were used as control groups. The operated legs were kept in long leg splints for three weeks with the ankle in 30 degrees of plantar flexion and the animals were left free in their cages. The animals were sacrificed at the end of eight weeks and the ATs were harvested. The harvested tendons, then, underwent biomechanical, histological and electron microscopic examination.

\section{Electron Microscopy Examination}

Six tendons from each group were used for histological and electron microscopic examination. Tendon pieces obtained from the healing region ( $4 \mathrm{~mm}$ in length and $2 \mathrm{~mm}$ in diameter) were held in $2.5 \%$ glutaraldehyde for 24 hours, washed with phosphate buffer, and fixed with osmium tetroxide. Afterwards, 10\% formaldehyde was applied to the samples for an hour and the samples were dehydrated in an environment with increasing alcohol concentration. The samples were washed with propylene oxide and were embedded in epoxy resin containing environment. $60 \mathrm{~nm}$ thick sections were obtained from the samples and were stained with uranyl acetate and lead on copper plates. ${ }^{[3]}$ These sections were examined under transmission electron microscopy (Joel JEM I 200 EX, Japon) with 20.000 magnification for collagen fibril density. At the beginning of the study, our aim was to measure the collagen fibril diameters with the help of electron microscopy in the control, percutaneous, and the open groups. However, the transverse sections of the tendon samples obtained from the healing regions in the open and percutaneous groups showed significant disorganized patterns of the collagen fibrils, preventing the measurement of the collagen fibrils.
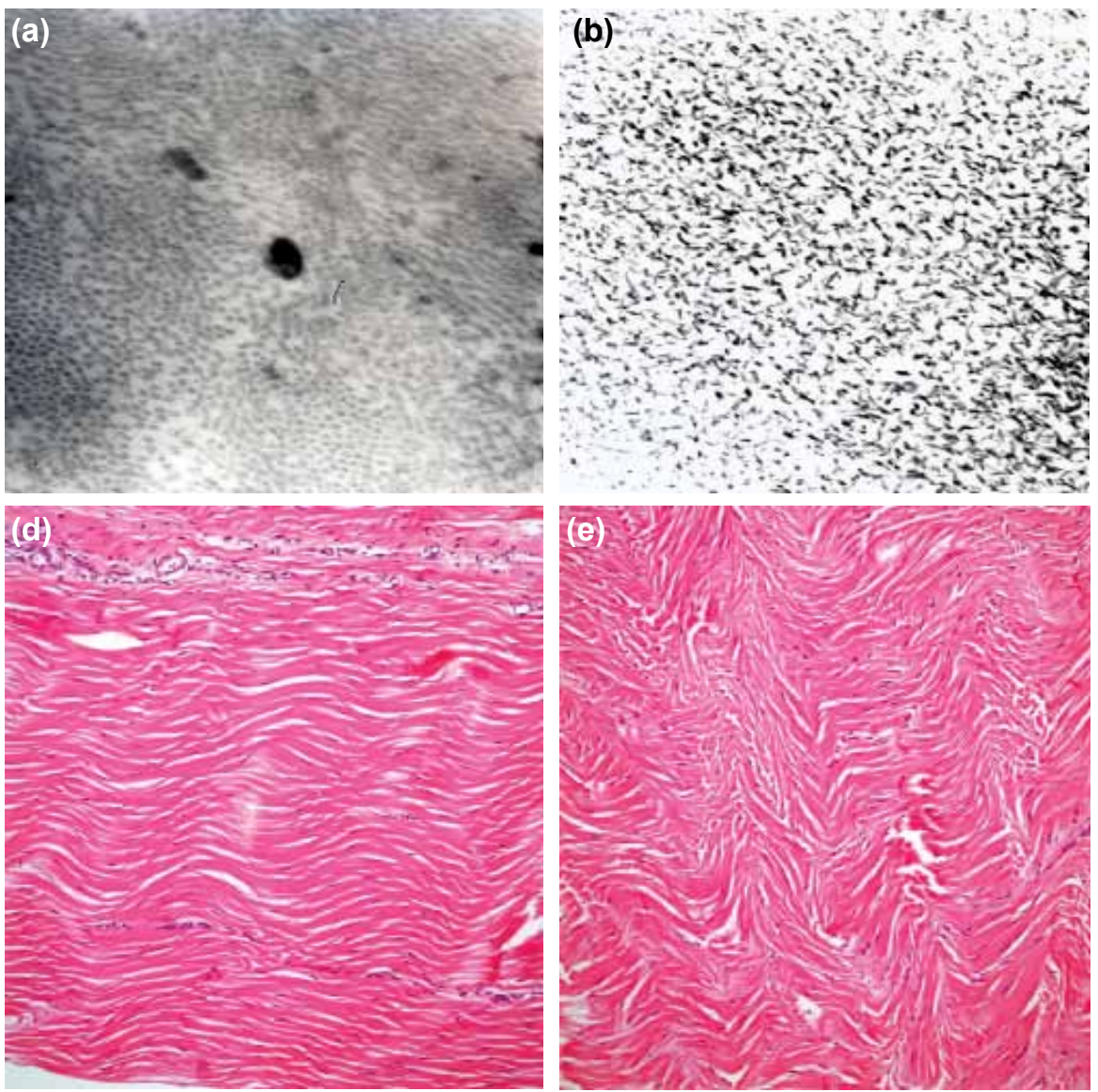

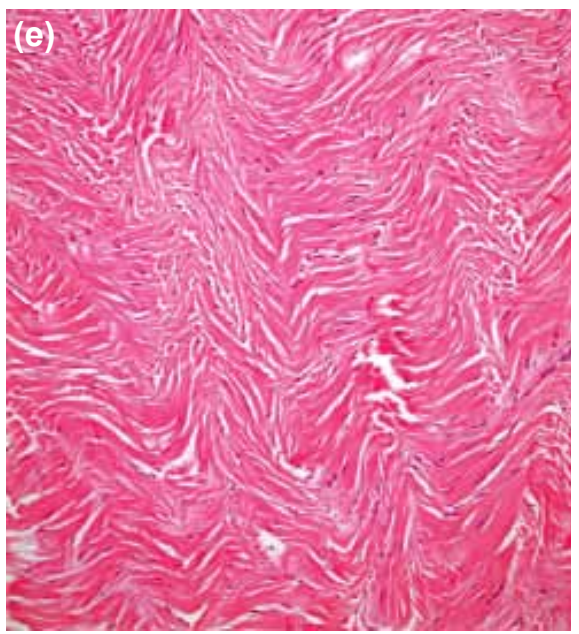

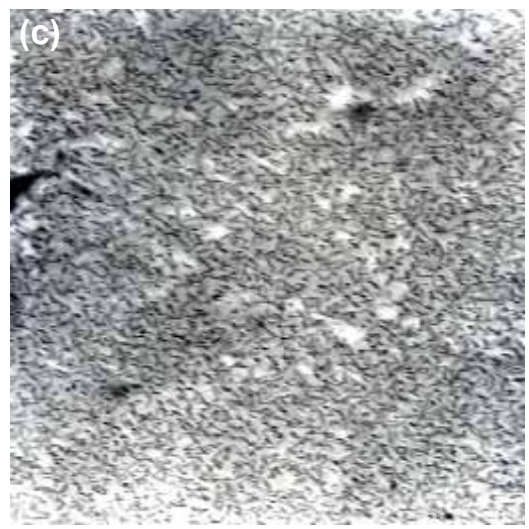

Figure 2. Electron microscopic sections in Control (a), Open (b) and Percutaneous (c) Groups, respectively (x20.000). The collagen fibrils in the open and the percutaneous groups were disorganized unlike the control tendon. The percutaneous group noted to have more abundant collagen fibrils than the open group. Light microscopy, hematoxylin eosin staining sections in Percutaneous (a) and Open (b) Groups (x40). Increased waviness and detachment between collagen bundles can be seen in the Open Group. 
Table I. Results of histological scoring for each group

\begin{tabular}{|c|c|c|c|c|c|c|c|c|c|}
\hline & \multirow[b]{3}{*}{ Scores } & \multicolumn{8}{|c|}{ Number of tendons for each score } \\
\hline & & \multicolumn{4}{|c|}{$\begin{array}{l}\text { Percutaneous group } \\
\qquad n=6\end{array}$} & \multicolumn{4}{|c|}{$\begin{array}{c}\text { Open group } \\
n=6\end{array}$} \\
\hline & & $\mathbf{0}$ & $\mathbf{I}$ & 2 & 3 & $\mathbf{0}$ & $\mathbf{I}$ & 2 & 3 \\
\hline Fibril structure & & & 4 & 1 & I & & & 4 & 2 \\
\hline Fibril arrangement & & & 2 & 3 & 1 & & & 3 & 3 \\
\hline Roundness of cell nuclei & & & 6 & & & & 4 & 1 & 1 \\
\hline Geographic heterogenity of cell density & & & 1 & 4 & $\mathrm{I}$ & & I & 3 & 2 \\
\hline Vascularity & & 5 & I & & & 5 & I & & \\
\hline Collagen staining & & & 4 & 2 & & & 2 & 3 & I \\
\hline
\end{tabular}

\section{Light Microscopy Evaluation}

Tendon pieces obtained from the healing region $(4 \mathrm{~mm}$ in length and $2 \mathrm{~mm}$ in diameter) were fixed in formalin solution buffered with $10 \%$ phosphate, dehydrated using a graded alcohol series, and embedded in paraffin blocks. Sections in $5 \mu \mathrm{m}$ thickness were obtained and stained with hematoxylin eosin. A standard grading system proposed by Movin et al. ${ }^{[32]}$ was used for histological examination under light microscopy (Zeiss, Carl Zeiss, Oberkochen, Germany). Being a four grade scoring system used to examine tendon structure, 0 represents normal structure; I mild deterioration from normal; 2 moderate deterioration; and 3 severe deterioration. Collagen fibril structure, fibril organization, roundness of the cell nucleuses, geographic heterogeneity of cell density, vascularity and collagen staining were examined and scored using this system. Higher scores represent more abnormal tendon structures.

\section{Biomechanical Evaluation}

Biomechanical testing was achieved in the Biomechanical Laboratories of the Middle East Technical University. Fourteen dissected ATs were mounted with special clamping jaws on the testing device (Lloyd, LS500, England) on each ends and the pull-out test was applied with a speed of $10 \mathrm{~mm} / \mathrm{min}^{\left[{ }^{[33]}\right.}$ The maximum rupture loads needed in Newton $(\mathrm{N})$ were recorded for the control and the study groups.

\section{Statistical Analysis}

Statistical analysis was performed with the Statistical Package for the Social Sciences (SPSS) version 12.0. The Student-t and Mann Whitney- $U$ tests were used to investigate differences between the mean force to rupture the tendons and histological scoring. Significance level was $p<0.05$.

\section{RESULTS}

\section{Electron Microscopy}

In all transverse sections obtained from the healed region of both groups, the collagen fibrils were noted to have disorga- nized arrangement. This was thought to be due to immaturity of the healed region where the collagen fibrils were not able to organize in parallel arrangement. When the sections were evaluated in terms of fibril density, it was noted that fibrils were more abundant in percutaneous repair group (Figs. 2a-c).

\section{Light Microscopy}

Examination of the fibril arrangement and structure revealed that the tendons in percutaneous group have more organized fibrillar structure and less waviness which is an indirect sign of tendon maturity. The sections obtained from percutaneous group showed less detachment between parallel collagen bundles (Figs. 2d, e) and it was noted that the bundles were more closely attached to each other. The arrangement of the collagen bundles in the percutaneous group resembled more like the control sections than the open group did. The open group had more polymorphonuclear cells causing a higher score in cell roundness which is an indirect sign of ongoing inflammation and healing. With respect to vascularity, both groups had mild vascularity without a significant difference. Geographic heterogeneity of cell density and collagen staining quality was similar in both groups. Overall, the tendon scores in the percutaneous group was less than the open group indicating closer histological morphology to normal; however, the difference was not significant (Table I) $(p=0.065)$.

\section{Biomechanical Evaluation}

The mean force to rupture the tendon in percutaneous group was measured 143.7 $\pm 9.5 \mathrm{~N}(132-159)$ and $191.1 \pm 9.7 \mathrm{~N}$ (184205) for the opposite control sides (Table 2). There was a significant difference between the percutaneous and the control groups $(p<0.001)$. The mean force to rupture the tendon in open group was measured 139.2 $\pm 8.2 \mathrm{~N}(126-152)$ and $196.4 \pm 8.2 \mathrm{~N}(\mid 85-210)$ for the opposite control sides. There was a significant difference between the open and the control groups $(p<0.001)$. Although the force needed to rupture the tendons were higher in the percutaneous group than in the open group, the difference was not statistically significant 
Table 2. Maximum force needed to rupture the tendons in each group and percentages with respect to control sides

\begin{tabular}{|c|c|c|c|c|c|c|}
\hline & \multicolumn{3}{|c|}{ Percutaneous group } & \multicolumn{3}{|c|}{ Open group } \\
\hline & $P(n)$ & Pc (n) & $\%$ & $0(n)$ & Oc (n) & $\%$ \\
\hline I & 146 & 184 & 79 & 126 & 198 & 63 \\
\hline 2 & 132 & 175 & 75 & 152 & 210 & 72 \\
\hline 3 & 136 & 185 & 73 & 145 & 195 & 74 \\
\hline 4 & 156 & 200 & 78 & 132 & 188 & 70 \\
\hline 5 & 138 & 189 & 73 & 144 & 204 & 71 \\
\hline 6 & 143 & 195 & 73 & 135 & 192 & 70 \\
\hline 7 & 159 & 205 & 77 & 138 & 185 & 74 \\
\hline Mean $\pm S D$ & $143.7 \pm 9.5$ & $191.1 \pm 9.7$ & $74.9 \pm 2.8$ & $139.2 \pm 8.2$ & $196.4 \pm 8.2$ & $70.6 \pm 3.5$ \\
\hline
\end{tabular}

$(p=0.33)$. The maximum force to rupture was also calculated as the percentage of the corresponding control side. The measurements revealed higher percentages in percutaneous group with a significant difference $(74.9 \% \pm 2.8 \%$ [73-79] in percutaneous group; $70.6 \% \pm 3,5 \%$ [63-74] in open group $[p=0.02])$.

\section{DISCUSSION}

The open and percutaneous AT repair techniques in a rabbit model were compared for histological, electron microscopical and biomechanical findings for the first time in the present study. The most important findings of the present study were more mature histological tendon structure and presence of more abundant collagen fibrils in the percutaneous group. In addition, when the mean force to rupture the tendons were calculated as the percentage of the control sides, the percutaneous group had better outcomes.

It is well known that as the healing progresses in the rupture area the tendon gets more mature and the histology resembles more like a normal tendon. The parallelism of the collagen fibrils increases; the angulations and the detachments around collagen bundles decreases; vascularity and cellular infiltration by polymorphonuclear and mononuclear cells decreases. ${ }^{[34]}$ With the histological scoring system, it was aimed to identify whether one of the treatment groups would resemble the normal tendon structure more than the other. It was assumed that the healing would take place faster in the percutaneous group since the paratenon and all the vascularity around the tendon was protected. Although there was no statistically significant difference between the groups, the results showed better tendon scores in the percutaneous group.

The mechanical strength of a collagen fibril is related to intramolecular bonding in its triple-helix structure and to its actual diameter. ${ }^{[31]}$ Collagen type III which has a smaller diameter than collagen type II is more abundant in tendons with de- generation and in healing process. ${ }^{[35]}$ Collagen fibril diameter increases as the tendons get more mature with more collagen type II; however, collagen fibrils were noted to have disorganized arrangement due to immaturity of the healing region. With regard to fibrillar density, fibrils were more abundant in the percutaneous repair group. Percutaneous group had more potential to produce fibrils with the paratenon and mesenchymal cells that were preserved and more numbers of collagen fibrils were noted in the healing area. How the collagen fibril abundance would affect the final outcome is unknown.

The healing process around the repair site starts with inflammatory response. Petrou et al. showed that the inflammatory response around the healing region consists mainly of lymphocytes and fewer eosinophils, neutrophils and giant cells causing a heterogeneity in the cell types. Although a direct comparison of our results with this study is impossible due to lack of quantitative data, our results show similar cell heterogeneity both in percutaneous and open groups. ${ }^{[6]}$ In another rabbit study comparing the effect of nicotine and saline on tendon healing, the investigators showed separation, slight waviness and loss of parallel arrangement of collagen fibers in the saline group which is similar to our open repair group. On the other hand, the percutaneous group in our study showed better collagen arrangement and less detachment between collagen bundles. ${ }^{[37]}$ The vascularization was substantially increased in both the saline and nicotine group in the same study, which is a well-accepted healing process similar to our findings in both the percutaneous and open group.

The goals of the treatment in AT ruptures are early return to pre-injury function level, minimization of morbidity, and prevention of complications. Although there are controversies in the treatment of fresh AT ruptures, surgical treatments are recommended in young and middle-aged active patients. ${ }^{[2,17,20,38,39]}$ Conservative treatments are dispensed due to complications related to skin, high re-rupture rates, tendon elongation and 
long recovery period. ${ }^{[17]}$ With the non-operative treatment, the tendon ends stay apart and gap forms between the two stumps leading to tendon elongation and muscle weakening. Open technique is associated with lower risk of re-rupture, provides faster rehabilitation and return to pre-injury activity level compared to non-operative treatment. ${ }^{[12]}$ However, it is associated with infection, problems with incision (dehiscence, delayed healing), scar adhesions and longer hospital stay. ${ }^{[23]}$ Percutaneous treatment aimed to reduce complications related to open surgery and lower the re-rupture rates associated with conservative treatment. Percutaneous treatment includes application of internal splint/sutures through the stab incisions around the rupture and protects paratenon and vascularity of the tendon with a theoretical benefit of increased healing potential. The technique is successful in terms of decreasing infection rates, preventing incision related complications and decreasing hospital costs but criticized for having high rates of sural nerve problems and not achieving optimum tendon stump apposition. ${ }^{[0]}$ Percutaneous AT repair technique is minimally invasive and the exposure of the rupture site is unnecessary, having good functional results, less complications (wound-healing, infection), less scarring, and faster recovery than open surgery. ${ }^{[20]}$ Percutaneous technique has been modified in different ways and sural nerve injury has reduced. Majewski et al. ${ }^{[4]}$ have reported no sural nerve injury with the percutaneous repair after exposing the nerve through a small lateral incision. Webb et al. ${ }^{[42]}$ have moved the lateral incisions more towards the midline staying away from the nerve and reported no nerve injury in twenty-seven patients. Doral et al. ${ }^{[20]}$ have reported endoscopy assisted percutaneous suturing of the AT under local anaesthesia in sixty-two patients, $95 \%$ of whom returned to their previous sportive activities. They have concluded that the percutaneous technique allows early rehabilitation, provides cosmetic wound appearance and endoscopic control would provide precise apposition of the tendon stumps. These studies show that it is possible to overcome the drawbacks of the percutaneous technique by modifying the original method. In a study using no external support after endoscopy-assisted AT repair and immediate rehabilitation, there has been no significant difference in both ankle muscle strength and lower extremity functional level between the endoscopy-assisted repairs and the unaffected sides. ${ }^{[43]}$

In a meta-analysis of randomized controlled trials comparing conventional open method with minimally invasive/percutaneous approaches for the repair of AT ruptures, no difference was reported in re-ruptures, sural nerve injury, deep infection or adhesions. ${ }^{[30]}$ Superficial wound infection was significantly higher in the open group. Patients were nearly three times more likely to report a good or excellent outcome following minimal invasive/percutaneous repair compared to open surgery. ${ }^{[30]}$ In another meta-analysis, the pooled rate of rerupture for open and percutaneous treatments were $4.3 \%$ and $2.1 \%$, respectively. ${ }^{[39]}$ The complication rate (excluding re-ruptures) in the open group was $26.1 \%$ versus $8.3 \%$ in the percutaneous group. In a randomized prospective study, no difference was reported in isokinetic evaluation of peak torque and total work in plantar and dorsal flexion. ${ }^{[4]}$

The current available data on open and percutaneous treatment of fresh AT ruptures reveal that both techniques have similar clinical and functional results. ${ }^{[43,44]}$ On the other hand, complications related to surgical site have been reported more commonly in the open procedures. Additionally, the present study showed that percutaneous technique had advantages over open technique as noted in histological scoring, electron microscopic findings and biomechanical testing in an animal model.

There were limitations in the present study. The tendon rupture was not a closed injury. A small stab incision was used to produce a tendon rupture, but the paratenon injury was kept minimum. The tendons used had no pre-existing structural tendon problem; however, in clinical settings, AT ruptures usually occur in tendons with existing degeneration or tendinosis. Therefore, the results may be different in abnormal tendons.

\section{Conclusion}

Comparison of percutaneous/mini-invasive and open surgical treatment of fresh AT rupture in an animal model revealed similar results in biomechanical testing. On the other hand, histologic examination showed that percutaneous/mini-invasive methods may be more advantageous in terms of tendon healing and maturation. However, it should be kept in mind that animal studies cannot be extrapolated directly to human beings.

Conflict of interest: None declared.

\section{REFERENCES}

1. Carden DG, Noble J, Chalmers J, Lunn P, Ellis J. Rupture of the calcaneal tendon. The early and late management. J Bone Joint Surg Br 1987;69:416-20.

2. Puddu G, Ippolito E, Postacchini F. A classification of Achilles tendon disease. Am J Sports Med 1976;4:145-50. CrossRef

3. Doral MN, Alam M, Bozkurt M, Turhan E, Atay OA, Dönmez G, Maffulli N. Functional anatomy of the Achilles tendon. Knee Surg Sports Traumatol Arthrosc 2010;18:638-43. CrossRef

4. Assal M, Jung M, Stern R, Rippstein P, Delmi M, Hoffmeyer P. Limited open repair of Achilles tendon ruptures: a technique with a new instrument and findings of a prospective multicenter study. J Bone Joint Surg Am 2002;84-A:161-70.

5. Dodds WN, Burry HC. The relationship between Achilles tendon rupture and serum uric acid level. Injury 1984;16:94-5. CrossRef

6. Clement DB, Taunton JE, Smart GW. Achilles tendinitis and peritendinitis: etiology and treatment. Am J Sports Med 1984;12:179-84. CrossRef

7. Mahler F, Fritschy D. Partial and complete ruptures of the Achilles tendon and local corticosteroid injections. Br J Sports Med 1992;26:7-14.

8. Vanek D, Saxena A, Boggs JM. Fluoroquinolone therapy and Achilles tendon rupture. J Am Podiatr Med Assoc 2003;93:333-5. CrossRef

9. Wilson AM, Goodship AE. Exercise-induced hyperthermia as a possible 
mechanism for tendon degeneration. J Biomech 1994;27:899-905. CrossRef

10. Mc Master PE. Tendon and muscle ruptures. Clinical and experimental studies on the causes and location of subcutaneous ruptures. J Bone Joint Surg 1933;15:705-22.

11. Tallon C, Maffulli N, Ewen SW. Ruptured Achilles tendons are signifcantly more degenerated than tendinopathic tendons. Med Sci Sports Exerc 2001;33:1983-90. CrossRef

12. Cetti R, Christensen SE, Ejsted R, Jensen NM, Jorgensen U. Operative versus nonoperative treatment of Achilles tendon rupture. A prospective randomized study and review of the literature. Am J Sports Med 1993;21:791-9. CrossRef

13. Neumayer F, Mouhsine E, Arlettaz Y, Gremion G, Wettstein M, Crevoisier X. A new conservative-dynamic treatment for the acute ruptured Achilles tendon. Arch Orthop Trauma Surg 2010;130:363-8. CrossRef

14. Costa ML, MacMillan K, Halliday D, Chester R, Shepstone L, Robinson $\mathrm{AH}$, et al. Randomised controlled trials of immediate weight-bearing mobilisation for rupture of the tendo Achillis. J Bone Joint Surg Br 2006;88:69-77. CrossRef

15. McComis GP, Nawoczenski DA, DeHaven KE. Functional bracing for rupture of the Achilles tendon. Clinical results and analysis of groundreaction forces and temporal data. J Bone Joint Surg Am 1997;79:1799808.

16. Roberts CP, Palmer S, Vince A, Deliss LJ. Dynamised cast management of Achilles tendon ruptures. Injury 2001;32:423-6. CrossRef

17. Metz R, Verleisdonk EJ, van der Heijden GJ, Clevers GJ, Hammacher ER, Verhofstad MH, et al. Acute Achilles tendon rupture: minimally invasive surgery versus nonoperative treatment with immediate full weightbearing-a randomized controlled trial. Am J Sports Med 2008;36:1688-94. CrossRef

18. Schmidt-Rohlfing B, Graf J, Schneider U, Niethard FU. The blood supply of the Achilles tendon. Int Orthop 1992;16:29-31. CrossRef

19. Olsson N, Silbernagel KG, Eriksson BI, Sansone M, Brorsson A, Nilsson-Helander K, et al. Stable surgical repair with accelerated rehabilitation versus nonsurgical treatment for acute Achilles tendon ruptures: a randomized controlled study. Am J Sports Med 2013;41:2867-76. CrossRef

20. Doral MN, Bozkurt M, Turhan E, Ayvaz M, Atay OA, Uzümcügil A, et al. Percutaneous suturing of the ruptured Achilles tendon with endoscopic control. Arch Orthop Trauma Surg 2009;129:1093-101. CrossRef

21. Nilsson-Helander K, Silbernagel KG, Thomeé R, Faxén E, Olsson N, Eriksson BI, et al. Acute achilles tendon rupture: a randomized, controlled study comparing surgical and nonsurgical treatments using validated outcome measures. Am J Sports Med 2010;38:2186-93. CrossRef

22. Haertsch PA. The blood supply to the skin of the leg: a post-mortem investigation. Br J Plast Surg 1981;34:470-77. CrossRef

23. Saxena A, Maffulli N, Nguyen A, Li A. Wound complications from surgeries pertaining to the Achilles tendon: an analysis of 219 surgeries. J Am Podiatr Med Assoc 2008;98:95-101.

24. Ma GW, Griffith TG. Percutaneous repair of acute closed ruptured achilles tendon: a new technique. Clin Orthop Relat Res 1977;128:247-55.

25. Bradley JP, Tibone JE. Percutaneous and open surgical repairs of Achilles tendon ruptures. A comparative study. Am J Sports Med 1990;18:188-95.

26. Mandelbaum BR, Myerson MS, Forster R. Achilles tendon ruptures. A new method of repair, early range of motion, and functional rehabilitation. Am J Sports Med 1995;23:392-5. CrossRef

27. Motta P, Errichiello C, Pontini I. Achilles tendon rupture. A new tech- nique for easy surgical repair and immediate movement of the ankle and foot. Am J Sports Med 1997;25:172-6. CrossRef

28. Webb JM, Bannister GC. Percutaneous repair of the ruptured tendo Achillis. J Bone Joint Surg Br 1999;81:877-80. CrossRef

29. Carmont MR, Maffulli N. Modified percutaneous repair of ruptured Achilles tendon. Knee Surg Sports Traumatol Arthrosc 2008;16:199-203.

30. McMahon SE, Smith TO, Hing CB. A meta-analysis of randomised controlled trials comparing conventional to minimally invasive approaches for repair of an Achilles tendon rupture. Foot Ankle Surg 2011;17:211-7.

31. Järvinen TA, Järvinen TL, Kannus P, Józsa L, Järvinen M. Collagen fibres of the spontaneously ruptured human tendons display decreased thickness and crimp angle. J Orthop Res 2004;22:1303-9. CrossRef

32. Movin T, Gad A, Reinholt FP, Rolf C. Tendon pathology in long-standing achillodynia. Biopsy findings in 40 patients. Acta Orthop Scand 1997;68:170-5. CrossRef

33. Ilhami K, Gokhan M, Ulukan I, Eray BM, Levent A, Ciğdem T. Biomechanical and histologic comparison of Achilles tendon ruptures reinforced with intratendinous and peritendinous plantaris tendon grafts in rabbits: an experimental study. Arch Orthop Trauma Surg 2004;124:608-13.

34. Woo SL, Hildebrand K, Watanabe N, Fenwick JA, Papageorgiou CD, Wang JH. Tissue engineering of ligament and tendon healing. Clin Orthop Relat Res 1999;(367 Suppl):312-23. CrossRef

35. Maffulli N, Ewen SW, Waterston SW, Reaper J, Barrass V. Tenocytes from ruptured and tendinopathic achilles tendons produce greater quantities of type III collagen than tenocytes from normal achilles tendons. An in vitro model of human tendon healing. Am J Sports Med 2000;28:499-505.

36. Petrou CG, Karachalios TS, Khaldi L, Karantanas AH, Lyritis GP. Calcitonin effect on Achilles tendon healing. An experimental study on rabbits. J Musculoskelet Neuronal Interact 2009;9:147-54.

37. Duygulu F, Karaoğlu S, Zeybek ND, Kaymaz FF, Güneş T. The effect of subcutaneously injected nicotine on achilles tendon healing in rabbits. Knee Surg Sports Traumatol Arthrosc 2006;14:756-61. CrossRef

38. Winter E, Weise K, Weller S, Ambacher T. Surgical repair of Achilles tendon rupture. Comparison of surgical with conservative treatment. Arch Orthop Trauma Surg 1998;117:364-7. CrossRef

39. Khan RJ, Fick D, Keogh A, Crawford J, Brammar T, Parker M. Treatment of acute achilles tendon ruptures. A meta-analysis of randomized, controlled trials. J Bone Joint Surg Am 2005;87:2202-10. CrossRef

40. Klein W, Lang DM, Saleh M. The use of the Ma-Griffith technique for percutaneous repair of fresh ruptured tendo Achillis. Chir Organi Mov 1991;76:223-8.

41. Majewski M, Rohrbach M, Czaja S, Ochsner P. Avoiding sural nerve injuries during percutaneous Achilles tendon repair. Am J Sports Med 2006;34:793-8. CrossRef

42. Webb JM, Bannister GC. Percutaneous repair of the ruptured tendo Achillis. J Bone Joint Surg Br 1999;81:877-80. CrossRef

43. Gigante A, Moschini A, Verdenelli A, Del Torto M, Ulisse S, de Palma L. Open versus percutaneous repair in the treatment of acute Achilles tendon rupture: a randomized prospective study. Knee Surg Sports Traumatol Arthrosc 2008;16:204-9. CrossRef

44. Cretnik A, Kosanovic M, Smrkolj V. Percutaneous versus open repair of the ruptured Achilles tendon: a comparative study. Am J Sports Med 2005;33:1369-79. CrossRef 


\section{Aşil tendon rüptürlerinin cerrahi tedavisi : Açık ve kapalı yöntemlerin tavşan modeli üzerinde karşılaştırılması Dr. Güney Yılmaz, ${ }^{1}$ Dr. Mahmut Nedim Doral, ${ }^{2}$ Dr. Egemen Turhan, ${ }^{2}$ Dr. Gürhan Dönmez, ${ }^{2}$ Dr. Ahmet Özgür Atay, ${ }^{2}$ Dr. Defne Kaya ${ }^{3}$}

1Selçuk Üniversitesi Tıp Fakültesi, Ortopedi ve Travmatoloji Anabilim Dalı, Konya;
${ }^{2}$ Hacettepe Üniversitesi Tıp Fakültesi, Ortopedi ve Travmatoloji Anabilim Dalı, Konya;
${ }^{3}$ Hacettepe Üniversitesi Tıp Fakültesi, Spor Hekimliği Anabilim Dalı, Ankara

AMAÇ: Tavşan aşil tendon (AT) rüptürü modeli üzerinde açık ve perkütan yöntemlerin iyileşme özelliklerini araştırmak ve iki grup arasında histoljik, elektron mikroskopik ve biyomekanik bulguları karşılaştırmak.

GEREÇ VE YÖNTEM: Yirmi altı adet tavşan her grupta 13 denek olacak şekilde rastlantısal olarak iki gruba ayrıldı. Tüm hayvanların sağ taraflarında AT'nin kalkaneusa yapışma bölgesinin $1.5 \mathrm{~cm}$ proksimalinde küçük bir insizyondan perkütan aşil tenotomisi uygulandı. Bunnel tarzı dikiş kullanılarak birinci grup açık yöntemle ikinci grup ise perkütan yöntem ile tedavi edildi. Sekiz hafta sonunda tendonlar biyemekanik ve histolojik değerlendirme amacıyla çıkartıldı. Tendonlar, fibriler yoğunluk için elektron mikroskobisiyle ve tendon iyileşme skorlaması için ise ışık mikroskopisi ile değerlendirildi. BULGULAR: Kesitler elektron mikroskopisi ile fibriler yoğunluk için değerlendirildiğinde perkütan grupta daha yoğun fibril yapısının olduğu görüldü. Tendon iyileşme skorları perkütan grupta daha düşük olmakla birlikte gruplar arasında anlamlı fark bulunmadı $(p=0.065)$. Ortalama tendon kopma

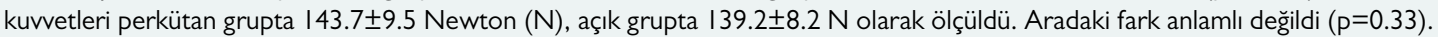

TARTIŞMA: Aşil tendon rüptürlerinde perkütan teknik en az açık teknik kadar iyi sonuçlar elde edilmesini sağlayabilir. Perkütan yöntemde tendon iyileşme dokusu daha iyi histolojik ve elektron mikroskopik bulgular gösterir. İki grup arasında erken dönemde biyomekanik olarak fark yoktur. Tendon iyileşmesine yardımcı olacak ve perkütan yöntemle beraber uygulanacak yeni yöntemlerin geliştirilmesi gelecek çalışmaların konusu olmalıdır. Anahtar sözcükler: Açık tamir; aşil tendonu; perkütan tamir.

Ulus Travma Acil Cerrahi Derg 2014;20(5):31 I-318 doi: 10.5505/tjtes.2014.427।6 